A N N A L E S

UNIVERSITATIS MARIAE CURIE-SKŁODOWSKA

LUBLIN - POLONIA

VOL. LXXIV

SECTIO B

2019

MAGDALENA SUCHORA

ORCID ID: 0000-0002-3210-8492

Maria Curie-Skłodowska University in Lublin

Institute of Earth and Environmental Sciences

magdalena.suchora@umcs.pl

\title{
An over 200-Year Environmental Change Record from the Highly Impacted Small, Hardwater Lake Pniówno (Chełm Hills)
}

Ponad 200-letni zapis zmian środowiska w osadach małego, twardowodnego jeziora Pniówno (Pagóry Chełmskie)

\begin{abstract}
Abstrakt: Artykuł przedstawia wyniki analiz paleoekologicznych i chemicznych osadów dennych małego, twardowodnego jeziora Pniówno. W profilu o niezaburzonej strukturze zanalizowano zmiany składu subfosylnej fauny wioślarek (Cladocera, Crustacea), oznaczono zawartość węgla organicznego, węglanów i krzemionki (z wydzieleniem frakcji terygenicznej i biogenicznej) oraz wiek osadów za pomocą datowania metodą ${ }^{210} \mathrm{~Pb}$. Dodatkowo, w oparciu o mapy archiwalne, przeanalizowano zmiany sieci wód powierzchniowych i użytkowania zlewni w okresie od początku XIX w. po czasy współczesne. Mimo powszechnego poglądu o pogarszającym się stanie wód powierzchniowych na skutek wzrostu presji antropogenicznej w okresie objętym analizą stwierdzono okresową poprawę stanu wód, którego przyczyną były najprawdopodobniej zmiany hydrologiczne i klimatyczne, umożliwiające rozwój roślinności zanurzonej, a także pustka osadnicza spowodowana działaniami podczas I wojny światowej.
\end{abstract}

Słowa kluczowe: subfosylne szczątki Cladocera; jezioro Pniówno; Pagóry Chełmskie; paleolimnologia; jakość wód; wpływ człowieka; Mała Epoka Lodowa

Abstract: The paper presents the results of paleoecological and chemical analyzes of bottom
sediments of the small hardwater lake Pniówno. In the sediment profile of undisturbed structure,
remains of subfossil Cladocera were analyzed, as well as the content of total organic carbon,
carbonates and silica (with separation of terrigenous and biogenic fractions). The age of sedi-
ments was determined by dating with the ${ }^{210} \mathrm{~Pb}$ method. In addition, changes in the surface water
network and catchment area were analyzed based on archival maps, covering the period from the
beginning of the $19^{\text {th }}$ century to modern times. Despite the widespread view of the deteriorating
state of surface waters as a result of increased anthropogenic pressure, the example of the shallow
Pniówno Lake indicates a periodic improvement in the state of water during the time covered
by the analysis. This was probably caused by hydrological and climatic changes enabling the
development of submerged macrophytes as well as settlement decline during the First World War. 
Keywords: subfossil Cladocera remains; Lake Pniówno; Chełm Hills; paleolimnology; water quality; human impact; Little Ice Age

\section{INTRODUCTION}

For the effective protection, management and sustainable use of lake ecosystems, vast knowledge on its functioning, as well as on the abiotic and biotic factors of its development are necessary (Smol 1992; Hennebelle et al. 2018). For this purpose, it is important to use long-term monitoring data covering periods when climatic and hydrological conditions or anthropogenic pressure had changed (Froyd, Willis 2008). However, due to the limited availability of instrumental monitoring data, in particular in relation to smaller lakes that are not covered by any form of protection, using proxy data that provides indirect information about changes of water quality and functioning of lake ecosystem might be the only way (Battarbee et al. 2005). Lake sediments provide a valuable insight into long-term changes within lakes and their catchments - these natural archives constantly record variation inside lakes and in their surroundings. Such change can be track further and interpreted by means of paleolimnological methods (Oldfield 1977).

The study presents the results of paleolimnological analysis (subfossil Cladocera, sediment chemistry) of sediment samples from a small, hardwater lake - Lake Pniówno. This lake, up to the first decade of the $19^{\text {th }}$ century, was one of the less studied among the so-called Łęczna-Włodawa lakes (Ferencz, Dawidek 2014). Indeed, only Radwan et al. $(1971 ; 1972 ; 1973)$ provide some hydrochemical data roughly characterizing the state of the lake in the mid-1960s. Also, little is known about the aquatic biocenosis of Lake Pniówno, as, since the studies of Kowalczyk (1977), no data have been published on the zooplankton composition of this waterbody, and the only data concerning macrophyte vegetation are given by Fijałkowski (1959) and further by Sugier et al. (2010).

Given the above, the main aim of the study was to trace changes in the ecological status of lake-catchment geo-ecosystem of Lake Pniówno, provided by paleolimnological proxies (Cladocera, sediment chemistry). Subfossil Cladocera remains are known to be a valuable source of information regarding such limnological parameters as climate, trophy of waters, lake level fluctuations or habitat diversity, including aquatic vegetation (Alhonen 1970; Korhola et al. 2000; Chen et al. 2010; Liu et al. 2014; Nevalainen et al. 2012). The insight into factors of the observed changes was derived mainly based on analysis of the catchment hydrological and land-use alterations of archive maps. 


\section{REGIONAL SETTINGS}

The small, shallow, polymictic Lake Pniówno (51¹4'47’N, 2320’32”E) is one of the Lęczna-Włodawa lakes - a unique group of 67 lakes located in Eastern Poland, over $200 \mathrm{~km}$ outside the range of the last glaciation. Their non-glacial origin makes the Łęczna-Włodawa lakes distinctive among the vast majority of Polish lakes. Located at southernmost peripheries of the group, Lake Pniówno is in the borderland of the Cretaceous Chelm Hills (part of the Polish Uplands) and the Polish Lowlands (Fig. 1). This lake, together with the nearby situated Słone, Syczyńskie and Tarnowskie lakes, are often considered as a distinctive sub-group among the Lęczna-Włodawa lakes, mostly due to their high quantity of the underground water supply and the hydrochemical properties of the lake waters (Dawidek 1998; Ferencz, Dawidek 2012).

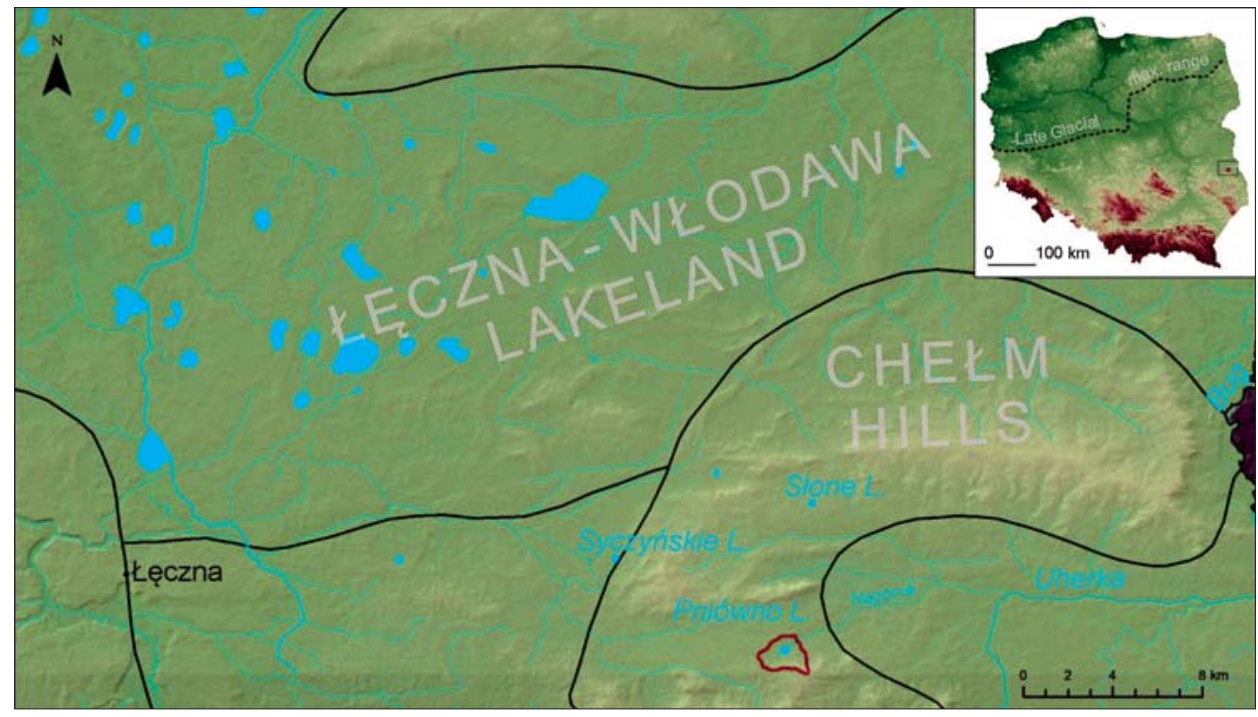

Fig. 1. Location of the study site. Red line - topographic catchment of Lake Pniówno, grey lines - regional division (after Chałubińska, Wilgat 1954)

Detailed morphometric and hydrochemical data regarding Lake Pniówno are summarized in Tab. 1 and 2. The lake's small area and volume, as well as the catchment area predominated by agricultural land use and rural settlement, place the lake among water bodies of high eutrophication risk (Toporowska et al. 2018). In 1950, the aquatic macrovegetation was scarce, with presence of stoneworts (Chara fragilis, Chara intermedia), watermilfoil Myriophyllum verticillatum, and, among the nympheids, pondweed Potamogeton natans, Nuphar luteum and Nymphaea candida. The lake was surrounded by the belt of emergent vegetation 
with cattail Typha angustifolia and reed Phragmites australis (Fijałkowski 1959). In 2005-2007, only one stonewort and three submerged macrophyte species were encountered with strong predominance of hornwort Ceratophyllum demersum and scarce presence of water soldier Stratiotes aloides (Sugier et al. 2010). Extensive phytoplankton development in the lake has been observed in recent years - summer phytoplankton blooms are mentioned by Sugier et al. (2010) and blue-green algae blooms -by Toporowska et al. (2018). Nowadays, the lake is supplied by small man-made tributaries, and one large outflow (Nagórnik ditch) discharges water towards the east, to the Lepietucha River, and, subsequently, to the Uherka River.

Lake Pniówno's topographic catchment is of complex character - its elevated, southern part is built upon cretaceous rocks, whereas sands, silts and organic sediments predominate in its lower part - in the immediate lake vicinity and northern part of the catchment (Buraczyński, Wojtanowicz 1988).

Tab. 1. Selected hydromorphological features of Lake Pniówno (based on literature data after ${ }^{(1)}$ Wilgat [1954], ${ }^{(2)}$ Ferencz and Dawidek [2014], ${ }^{(3)}$ Ferencz et al. [2017]).

\begin{tabular}{|l|c|c|}
\hline \multicolumn{1}{|c|}{ Parameter } & $1953 \mathrm{AD}^{(1)}$ & 2008-2010 $\mathrm{AD}^{(2)}$ \\
\hline Lake area [ha] & 7.7 & 5.25 \\
\hline Max. depth $[\mathrm{m}]$ & 3.9 & 2.71 \\
\hline Average depth $[\mathrm{m}]$ & 1.60 & $1.20^{(3)}$ \\
\hline Volume $\left[\mathrm{m}^{3}\right]$ & 121 & 85.55 \\
\hline
\end{tabular}

Tab. 2. Selected hydrochemical parameters of Lake Pniówno (based on literature data after ${ }^{(1)}$ Radwan et al. [1971; 1972; 1973], based on single measurement - 19.05.1967; ${ }^{(2)}$ Sugier et al. [2010], based on single measurement, summer season; ${ }^{(3)}$ Toporowska et al. [2018], seasonal measurements during the vegetation season - spring, summer, autumn: mean, range)

\begin{tabular}{|c|c|c|c|}
\hline Parameter & $\begin{array}{l}1967 \\
\mathrm{AD}^{(1)}\end{array}$ & $\begin{array}{l}2006-2007 \\
\mathrm{AD}^{(2)}\end{array}$ & $2008-2010^{(3)}$ \\
\hline $\mathrm{pH}$ & 7.8 & 8.1 & $7.7(7.2-8.1)$ \\
\hline Conductivity $[\mu \mathrm{S} / \mathrm{cm}]$ & n.d. & 382 & $566(529-607)$ \\
\hline Secchi depth [m] & 1.06 & 1.4 & $1.2(1.05-1.50)$ \\
\hline Chlorophyll $-a[\mu \mathrm{g} / \mathrm{l}]$ & n.d. & 14 & n.d. \\
\hline Total phosphorus TP [mg/l] & 0.046 & 0.05 & $0.163(0.133-0.208)$ \\
\hline Total nitrogen TN [mg/l] & n.d. & 1.9 & n.d. \\
\hline $\mathrm{Ca}[\mathrm{mg} / \mathrm{l}]$ & 80.2 & n.d. & n.d. \\
\hline $\begin{array}{l}\text { Trophy Status Indicator, TSI } \\
\text { (Carlson 1977) }\end{array}$ & n.d. & $\begin{array}{c}59.2 \\
\left(\text { mean } \text { TSI }_{\mathrm{SD}}, \mathrm{TSI}_{\mathrm{TP}}, \mathrm{TSI}_{\mathrm{N}}, \mathrm{TSI}_{\mathrm{chl}-\mathrm{a}}\right)\end{array}$ & $\begin{array}{c}63 \\
\left(\text { mean } \mathrm{TSI}_{\mathrm{SD}}, \mathrm{TSI}_{\mathrm{TP}}\right)\end{array}$ \\
\hline
\end{tabular}

Note: n.d. - no data. 


\section{MATERIALS AND METHODS}

Sediment sampling was performed during 2010 winter season. The $56-\mathrm{cm}$ sediment core of olive-brown algae-carbonate gyttja was collected with a Uwitec gravity corer ( $6 \mathrm{~cm}$ inner diameter), from the central part of the basin (Pni-A, at $\left.51^{\circ} 14^{\prime} 46,81^{\prime \prime} \mathrm{N}, 23^{\circ} 20^{\prime} 32,56^{\prime \prime} \mathrm{E}\right)$, at water depth of $2.65 \mathrm{~m}$. Directly after sampling, the sediments were cut into $1 \mathrm{~cm}$ slices, packed in plastic and kept at $4^{\circ} \mathrm{C}$ until the laboratory work was undertaken.

\section{AGE DETERMINATION}

The sediment sequence was dated utilizing the ${ }^{210} \mathrm{~Pb}$ method, in the Laboratory of Institute of Geological Sciences, Polish Academy of Science in Warsaw. For ${ }^{210} \mathrm{~Pb}$ analysis, a volumetric sample $\left(3 \mathrm{~cm}^{3}\right)$ of homogenized sediment was taken from each level. For all sediment samples bulk density and water content were determined. Herein, samples were dried at $105^{\circ} \mathrm{C}$ to constant weight, and homogenized in an agate mortar. The ${ }^{210} \mathrm{~Pb}$ activity of sediments was determined indirectly by alpha-spectrometry measurement of ${ }^{210} \mathrm{Po}(\mathrm{E} \alpha=5.31 \mathrm{MeV}, \mathrm{T} 1 / 2=$ 138 days) activity in 0.1-0.9 g sub-samples (Flynn 1968). Polonium was separated from the sample using concentrated hydrochloric and nitric acids and was deposited on silver disks (Flynn 1968). For complete removal of organic matter, $30 \%$ perhydrol was used. Polonium was deposited on silver disks. The activity of ${ }^{210} \mathrm{Po}$ and ${ }^{208} \mathrm{Po}$ was measured via an alfa OCTETE PC spectrometer produced by EG\&G ORTEC. In doing so, a known amount of ${ }^{208} \mathrm{Po}(\mathrm{E} \alpha=5.11 \mathrm{MeV})$ was added to the weighed sample as an internal yield tracer, and the constant rate of unsupported ${ }^{210} \mathrm{~Pb}$ supply model (CRS) was used to calculate the sediment age (Appleby 2001). Supported ${ }^{210} \mathrm{~Pb}$ was determined by measurements on old sediments (older than $150-200$ years) that contain no allochthonous ${ }^{210} \mathrm{~Pb}$, assuming constant activity of authigenic ${ }^{210} \mathrm{~Pb}$ along the sediment column. For samples over the extent of the dating method, age was determined by extrapolation of sedimentation rate of the lowermost samples. An age-depth function was calculated using the randomization method and was fitted by means of the LOESS procedure (Clevland, Devlin 1988).

\section{CLADOCERA ANALYSIS}

The laboratory preparation of cladoceran remains followed the procedure described by Szeroczyńska and Sarmaja-Korjonen (2007). Volumetric samples $\left(1 \mathrm{~cm}^{3}\right.$ of wet sediments) were treated with $10 \% \mathrm{HCl}$ to eliminate carbonates, and 
heated in $10 \% \mathrm{KOH}$ for 15 minutes to remove organic matter. After each stage of chemical preparation, the residue was washed through a $33 \mu \mathrm{m}$ mesh sieve with distilled water. A measured volume of $10 \mathrm{ml}$ of the final residue was then stained with safranine and quantitatively subsampled for microscope slides. For each slide, a $0.1 \mathrm{ml}$ of well-stirred sample was taken. Depending on frequency of remains, from 2 to 4 slides were prepared from each sample. All identifiable body parts of Cladocera were counted - shells, headshields, postabdomens, postabdominal claws and ephippia. Due to high dominance in the population of three taxa (Bosmina longirostris, Alona rectangula and Chydorus sphaericus), the number of 400 specimens was set as a minimum counting sum in order to properly include less abundant species. Additionally, to the Cladocera, plant remains were also counted (Ceratophyllum hairs, Nymphaeaceae statoblasts, Chara oospores). The identification of cladoceran remains and taxonomic nomenclature followed Szeroczyńska and Sarmaja-Korjonen (2007). For each species, the most numerous body part was chosen to represent the number of individuals. Total Cladocera abundance was expressed as the number of individuals per $1 \mathrm{~cm}^{3}$ of fresh sediments. The diagram of percentage share of Cladocera species was prepared with Tilia software (Grimm 1992), and the biotic indexes: species richness $(n)$, species diversity (expressed as Shannon-Weiner diversity index, $H^{\prime}$ ), and dominance $(D)$ were calculated and plotted with PAST (Hammer et al. 2001). Identification of Cladocera phases, reflecting lake-development stages, was supported via the cluster analysis method, using the CONISS algorithm (Grimm 1992). Calculation were made for square root transformed percentage data to downweigh dominants, while Edwards and Cavalli Sforza's chord distance were used as a similarity measure.

\section{CHEMICAL ANALYSIS}

Geochemical analyzes of the sediments were carried out in $1 \mathrm{~cm}$ thick layers with a 5-centimeter resolution, corresponding to that of the subfossil Cladocera analysis. Content of the organic matter (total organic carbon, TOC) and carbonates (TIC) were determined in approx. $2 \mathrm{~g}$ samples, by loss-of-ignition method, at $550^{\circ} \mathrm{C} / 4 \mathrm{~h}$ and $950^{\circ} \mathrm{C} / 6 \mathrm{~h}$, respectively (Heiri et al. 2001). Terrigenous and total silica were also determined in approx. $1 \mathrm{~g}$ samples of ignited sediment (residue after determination of TOC) according to the methodology given by Woszczyk (2011). The biogenic silica content was calculated as the difference between the mass of total and terrigenous silica. Cluster grouping and principal component analysis of TOC, carbonates, biogenic and terigenic silica (percentage data) were used to analyze the data. 


\section{ARCHIVAL MAPS ANALYSIS}

The analysis of changes in the lake-catchment settings was conducted with the application of 6 maps, listed in Tab. 3. Quantitative data was obtained by screen digitalization of calibrated map scans. These were calibrated and subjected to cartometric measurements in ArcMap 10.6, in accordance to the rules of historical GIS (Affek 2013; Kuna 2015). The areas of Lake Pniówno and other standing waters, wetlands, forests and length of watercourses were measured, and the results were presented in the form of maps (Fig. 3) and table (Tab. 3). In addition, to illustrate the development of the settlement network, built-up areas and the road layout were also vectorized, however, no quantitative analyzes were carried out. Due to development of drainage network and substantial spatial changes of the topographic watershed within the analyzed time span (Fig. 4), a rectangular test area of $14.54 \mathrm{~km}^{2}$ with the centrally located lake topographic catchment (established based on the elevation model, regardless of the drainage network) was designated for contextual analysis. The measurement results on the map of West Galicia (Carte von West-Gallizien) and the Topographic Card of the Kingdom of Poland (Topograficzna Karta Królestwa Polskiego), due to their non-cartometric character, are only approximate and cannot be treated as quantitative data. However, while conducting GIS measurements on the oldest maps was hindered, their hydrographic content concerning analyzed area was presented in great detail.

\section{RESULTS}

\section{Sediment age}

Activity of ${ }^{210} \mathrm{~Pb}$ were determined for 16 sediment samples of the Pni-A profile. The obtained values decline with depth, which indicates lack of profound sediment mixing. Activity of autogenic $\mathrm{Pb}$ was determined as $0.013+/-0.009$ Bq/g (Fig. 2a), and value equal to the background level were found at a depth of $31 \mathrm{~cm}$. The age-depth model indicates an increase of accumulation rate at the upper section of the core - from $23 \mathrm{~cm}$ upward (Fig. 2b). Due to being out of reach of the ${ }^{210} \mathrm{~Pb}$ method, the age of the lowermost samples $(>40 \mathrm{~cm})$ are only an estimation with considerable uncertainty. 


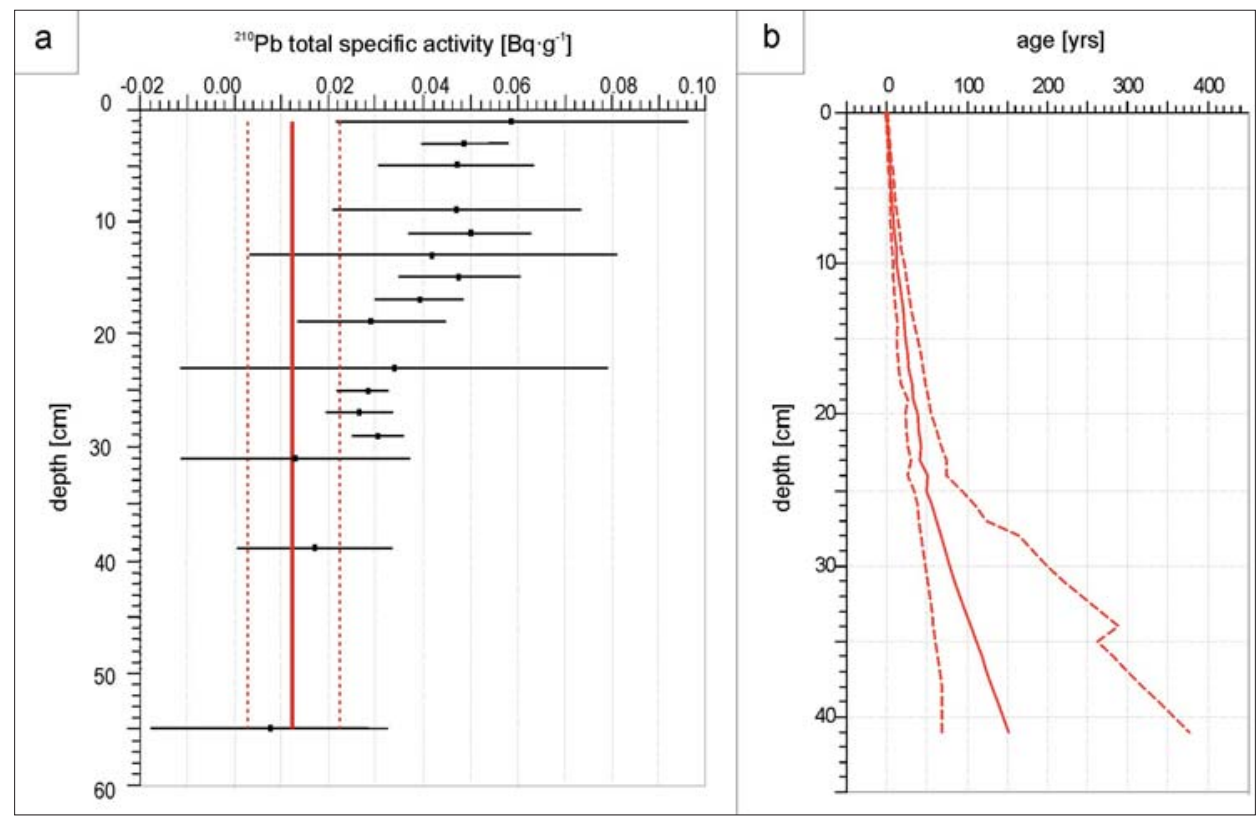

Fig. 2. $\mathrm{a}-{ }^{210} \mathrm{~Pb}$ activity in the Pni-A profile; $\mathrm{b}$ - age-depth model (solid line), with $95 \%$ confidence interval (dash lines)

\section{Hydrological alterations and catchment land use}

The maximum range of wetlands and forests in the analyzed period was found to have been in the first half of the $19^{\text {th }}$ century (Tab. 3, Fig. 3a, b), pointing to a low degree of environmental transformation. However, even at this time, drainage ditches within the wetlands surrounding the lake are evident - a ditch and pond (most probably fishpond), which were already marked on the oldest map (beginning of the $19^{\text {th }}$ century, Fig. 3a). Further drainage works covered the area of peatland north to the lake (Fig. 3b).

In the last decade of the $19^{\text {th }}$ century, significant drainage and deforestation is noticeable when compared to the first half of the $19^{\text {th }}$ century, mainly in the area north of the topographic catchment (Tab. 3, Fig. 3c). This came about most likely due to transformation of the wetlands and forests into agricultural land. The drying and deforestation works could have been associated with the development of the village of Wierzbica (buildings in the northwestern part of the analyzed area). Lake area declined by 1 ha as compared to the first half of the $19^{\text {th }}$ century.

The map from the 1930s reveals a reduced ring of wetlands around the lake. Moreover, the surface area of the lake itself points to a lowered water level (Fig. 3d). A drainage ditch in the western part of the drainage basin, the purpose of which was to supply water to the lake, may indicate deliberate measures to 


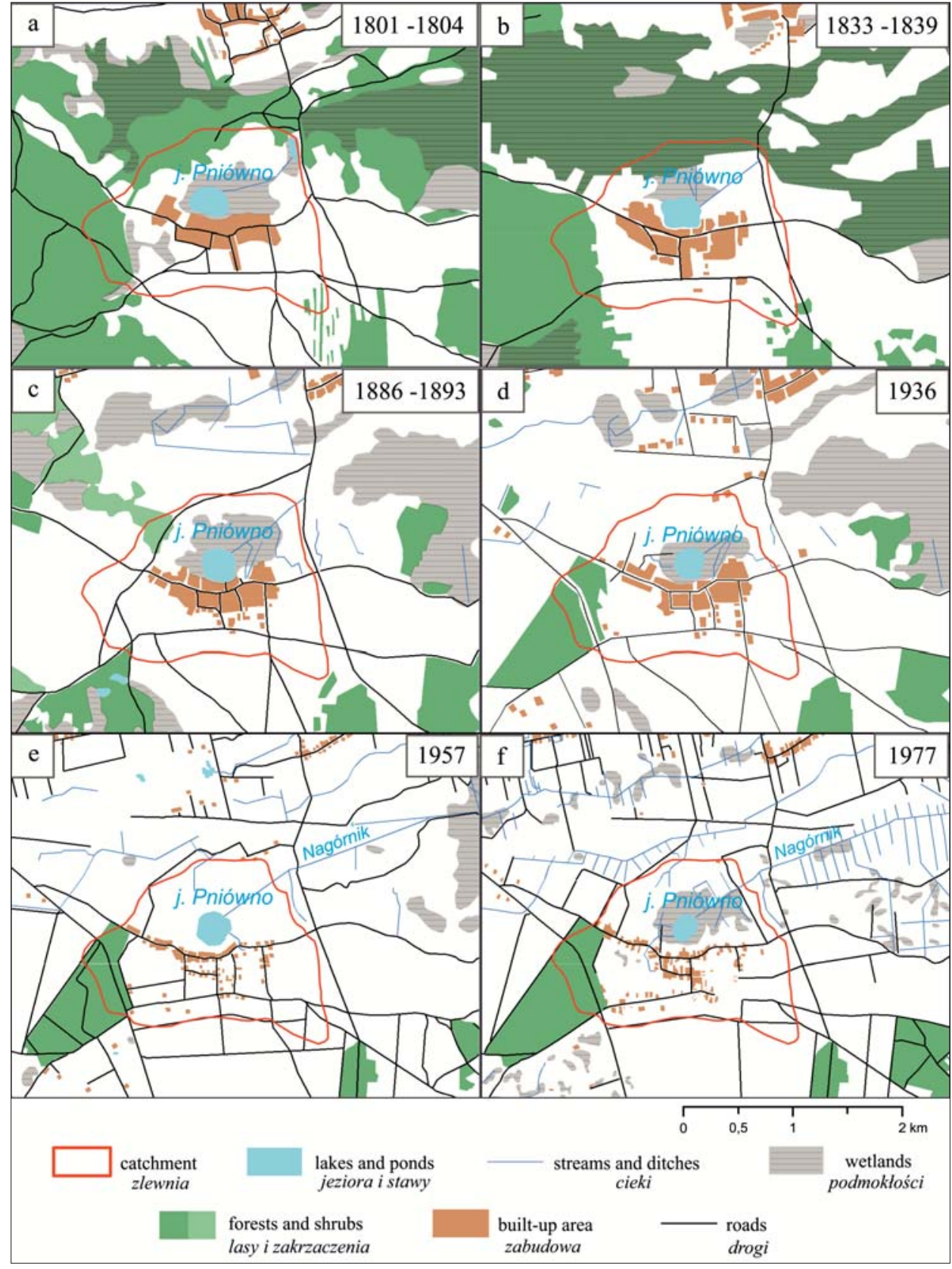

Fig. 3. Changes in land-use and hydrological network in Lake Pniówno's catchment and its surroundings (author's study based on archival maps) 
MAGDALENA SUCHORA

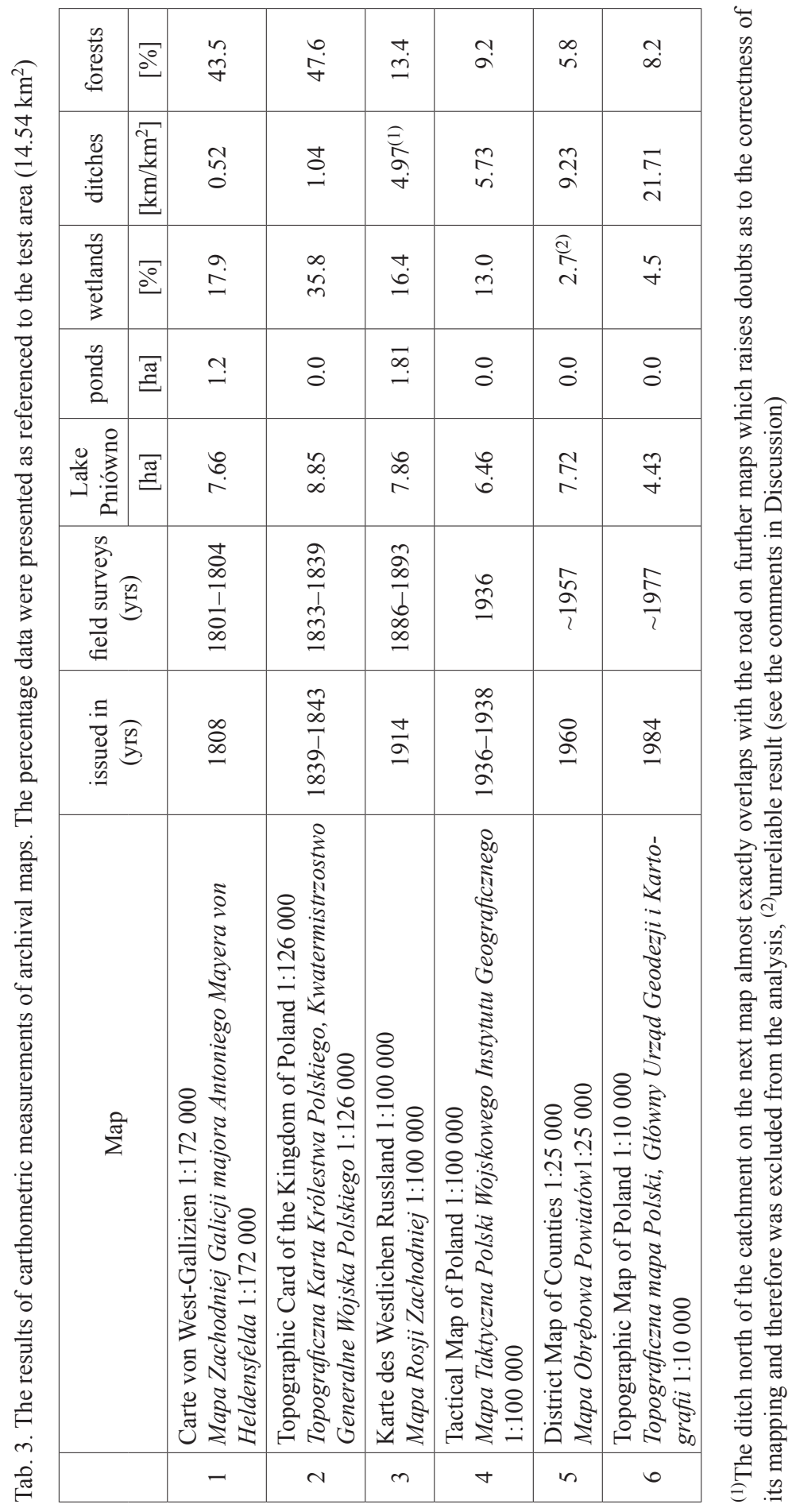




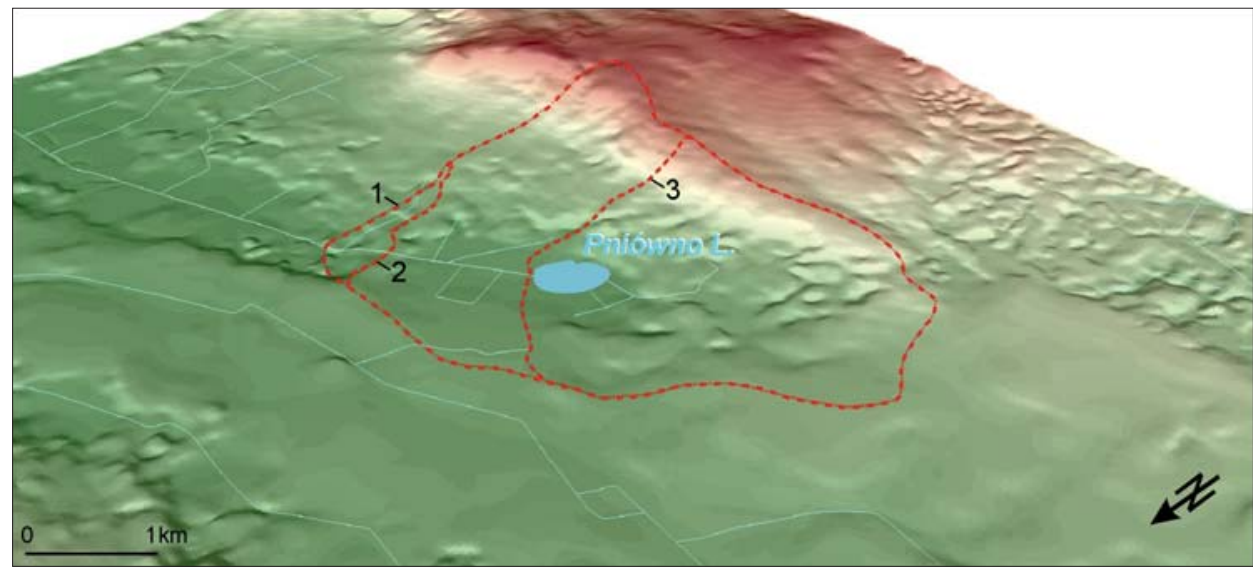

Fig. 4. Digital elevation model of Lake Pniówno catchment, dash line - changes of topographic catchment: 1 - beginning of the $19^{\text {th }}$ century until the $1830 \mathrm{~s} ; 2$ - the $1930 \mathrm{~s} ; 3$ - since the $1950 \mathrm{~s}$. Stream network reflects 2010 AD (author's own study based on Topographic Map of Poland $1: 10000)$

sustain water level. In addition, the reduced length of the ditch on the north-eastern side of the lake suggests that water was not discharged from the catchment, which most closely resembled its natural, topographic range (Fig. 4). Settlement, however, continued to develop, including in the lake catchment area (individual buildings in its northwestern part).

The most important change in hydrological setting, shown on Mapa Obrębowa Powiatów ( 1959 AD), was the "opening" of the topographic catchment by construction of the outflow from the lake towards the Nagórnik ditch. Its existence was reported even earlier (1953 AD) by Wilgat (1954). This ditch provides permanent outflow from the lake to the Uherka River basin. The map also shows the increased (relative to the 1930s map) extent of the lake. What is more, the lake surface and water level are higher than shown on the further topographic map (Topograficzna mapa Polski). However, the total lack of wetland around the lake, which is not marked on the map, is questionable. The unreliable of the mapping regarding the extent of wetlands on Mapa Obrębowa Powiatów is also confirmed by other authors pointing this source as being the least reliable among the $19^{\text {th }}$-century topographic maps (Mięsiak-Wójcik 2018).

Topographic map 1:10 000 presents in great detail the state of the catchment and its intermediate vicinity in the late 1970s. Therein, the lake area and lake level were the lowest in the whole analyzed period and the drainage network was at the greatest expansion. The area of wetlands diminished by over $30 \%$ with regard to the situation presented on Tactical Map of Poland. 


\section{Subfossil Cladocera analysis}

Remains of 22 Cladocera species belonging to three families (Daphniidae, Bosminidae and Chydoridae) were found in the sediments of the Pni-A core. Species richness $(n)$ within subsamples was between 8 to 18. Total Cladocera abundance ranged from 6,000 to 47,000 ind. $/ \mathrm{cm}^{3}$. Species diversity measured by the Shannon-Weiner index $\left(H^{\prime}\right)$ was from 0.71 to 1.52 , whereas dominance $(D)$ varied from 0.3 to 0.6 . Species Bosmina longirostris dominated in the entire profile, with percentage from 35 to $80 \%$. Subdominant taxa were Chydorus sphaericus s.l. ( 8 to $40 \%$ ) and Alona rectangula (8 to 20\%). Share of planktonic species differed from 35 to $80 \%$, whereas the littoral was from 20 to $65 \%$. Based on the identification results, two phases of Cladocera development were distinguished: CAZ-1, CAZ-2, with sub-phases (CAZ-2a, 2b).

CAZ-1 phase (44-55 cm, > 1865 AD). Only 15 cladoceran taxa were identified in this phase (Fig. 5, 6), with species richness within sub-samples ranging from 9 to 14. Of these, Bosmina longirostris (74-79\%) was of highest abundance in all the samples, with Alona rectangula (9-13\%) and Chydorus sphaericus $(10-11 \%)$ as sub-dominants. In this phase, taxa associated with high trophic status dominated - besides the aforementioned, these were also represented by Pleuroxus uncinatus, Oxyurella tenuicaudis and Leydigia acanthocercoides. Among planktonic taxa, Daphnia longispina gr. was present. A characteristic feature of this phase of cladoceran development were very high total Cladocera abundance $\left(38,800-47,200 \mathrm{ind} . / \mathrm{cm}^{3}\right)$, low diversity $\left(H^{\prime}: 0.71-0.85\right)$ and high dominance $(D: 0.58-0.64)$.

CAZ-2 phase (0-43 cm, 1845-2010 AD). In this phase 21 taxa were present. As before, the dominant species were Bosmina longirostris, Alona rectangula and Chydorus sphaericus. However, during this phase, a noticeable increase in the share of macrophyte-associated littoral species, as well as species associated with sediment substrate were noted. Moreover, a marked decrease of abundance of Bosmina longirostris was observed. The share of species associated with high trophy of waters had not changed significantly. In this phase two sub-phases were distinguished:

Sub-phase 2a (22-43 cm, $1845-1960$ AD). This sub-phase is marked by substantial decrease of Bosmina longirostris, whereas Chydorus sphaericus reaches its maximum abundance (23-43\%). A slight but steady increase in numbers of Alona rectangula (13-17\%) was also noted. In the mid- of the subphase, the decline of planktonic species was compensated by increase of the littoral, plant-associated (Graptoleberis testudinaria, Alona affinis, Pleuroxus trigonellus, Alonella exigua), as well as sediment-associated species (Pleuroxus 


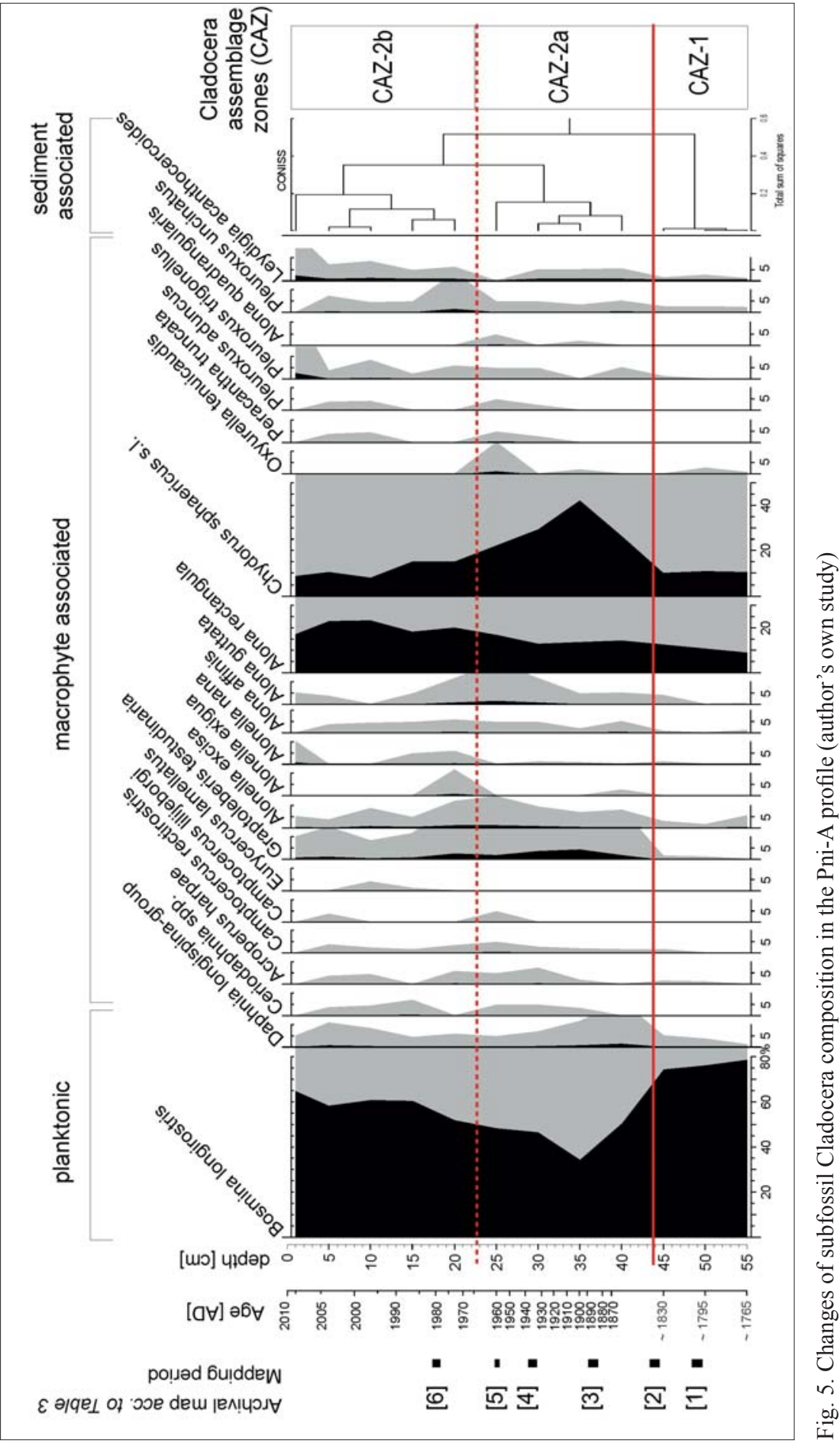




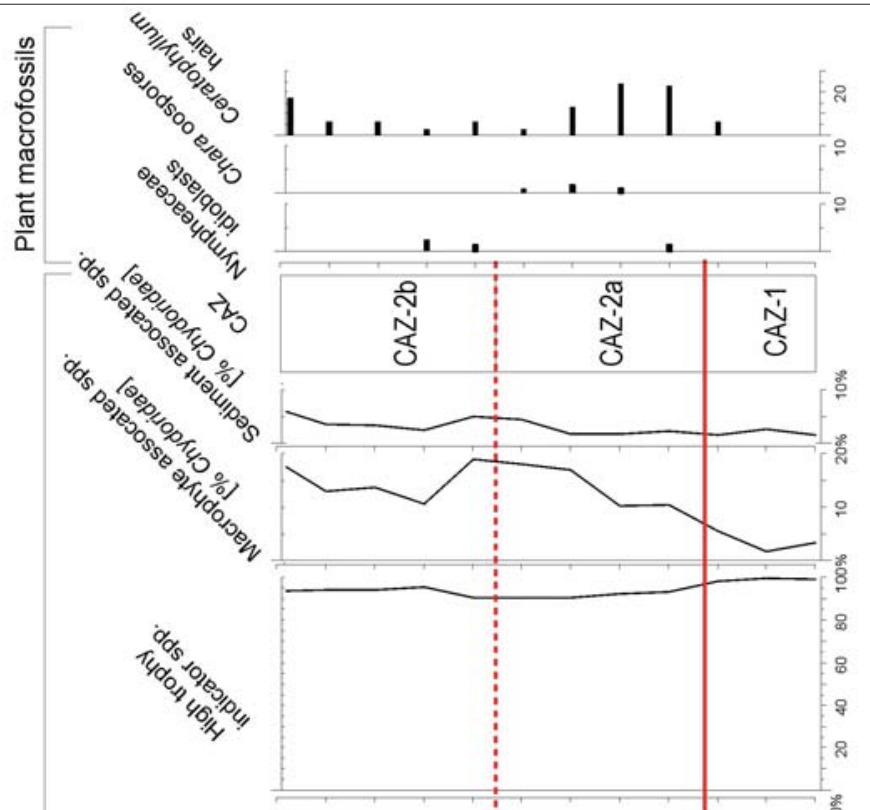

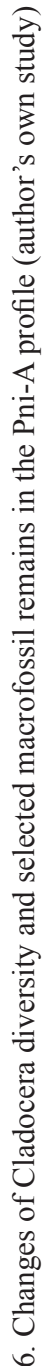


uncinatus, Alona quadrangularis). Taxa Alona quadrangularis occurred solely during this sub-phase. The end of the sub-phase was marked by the appearance of Alona guttata, Oxyurella tenuicaudis, Pleuroxus uncinatus and Camptocercus lillijeborgi.

For the entire sub-phase, decline in total Cladocera abundance $(10,800$ $\left.30,600 \mathrm{ind} . / \mathrm{cm}^{3}\right)$ and dominance $(D: 0.32-0.35)$ was evident. At the same time, the diversity index $\left(H^{\prime}: 1.34-1.52\right)$ and the species richness $(n: 13-18)$ were the highest within the entire profile.

Sub-phase 2b $(0-22 \mathrm{~cm}, \sim 1967-2009$ AD). In this sub-phase an increase in abundance of Bosmina longirostris and Alona rectangula was seen. At the onset of this sub-phase, the many of the species present in the earlier sub-phase declined until complete decay (Acropeus harpae, Camptocercus rectirostris, Alonella exigua, Alona affinis, Peracantha truncata, and Camptocercus lillijeborgi). In the mid part of sub-phase 2b, Eurycercus lamellatus makes the only appearance in the studied sediment sequence, and at the end of sub-phase, the increase of Alonella nana, Pleuroxus trigonellus and Leydigia acanthocercoides was notable.

In sub-phase $2 \mathrm{~b}$, decline in total Cladocera abundance $\left(6,500-21,800 \mathrm{ind} . / \mathrm{cm}^{3}\right)$ and species richness were indicated ( $n: 10-18)$, as well as an increase in dominance $(D: 0.41-0.46)$ and decline in diversity $\left(H^{\prime}: 1.16-1.48\right)$. The decline of littoral taxa (similarly to Cla-1) - mostly the plant-associated - was seen, whereas sediment-associated taxa increased, especially these adapted to high trophy and low oxygen conditions (Leydigia acanthocercoides).

\section{GEOCHEMICAL ANALYSIS}

Three geochemical zones were identified (Fig. 7) based on changes of total organic carbon (TOC), carbonates and two forms of silica $\left(\mathrm{SiO}_{2}\right.$ biog, $\left.\mathrm{SiO}_{2 \text { ter }}\right)$.

GZ-1 (depth 40-55 cm, > 1865 AD). In this zone, the highest values of total organic carbon $(45.5 \% \pm 0.98)$ and both forms of biogenic and terrigenous silica were noted $(9.8 \% \pm 1.7$ and $21.6 \% \pm 1.1$, respectively), whereas calcium carbonate levels oscillate around $21 \%(21.4 \% \pm 1.2)$, which were the lowest values in the entire examined sediment section.

GZ-2 (depth 15-35 cm, 1900 - 1987 AD). Herein, values of sedimentary calcium carbonate $(33.6 \% \pm 4.0)$ were substantially higher than in GZ-1, with increasing trend. In addition, a simultaneous decline of TOC $(34.6 \% \pm 2.8)$, as well as terrigenous silica $(9.3 \% \pm 1.8)$, were typical for the zone.

GZ-2a (depth 20-35 cm, 1900 - 1970 AD) and GZ-2b (depth 10-15 cm, $\sim 1970$ - 2000 AD) sub-zones were delimited base on the reverse of declining 


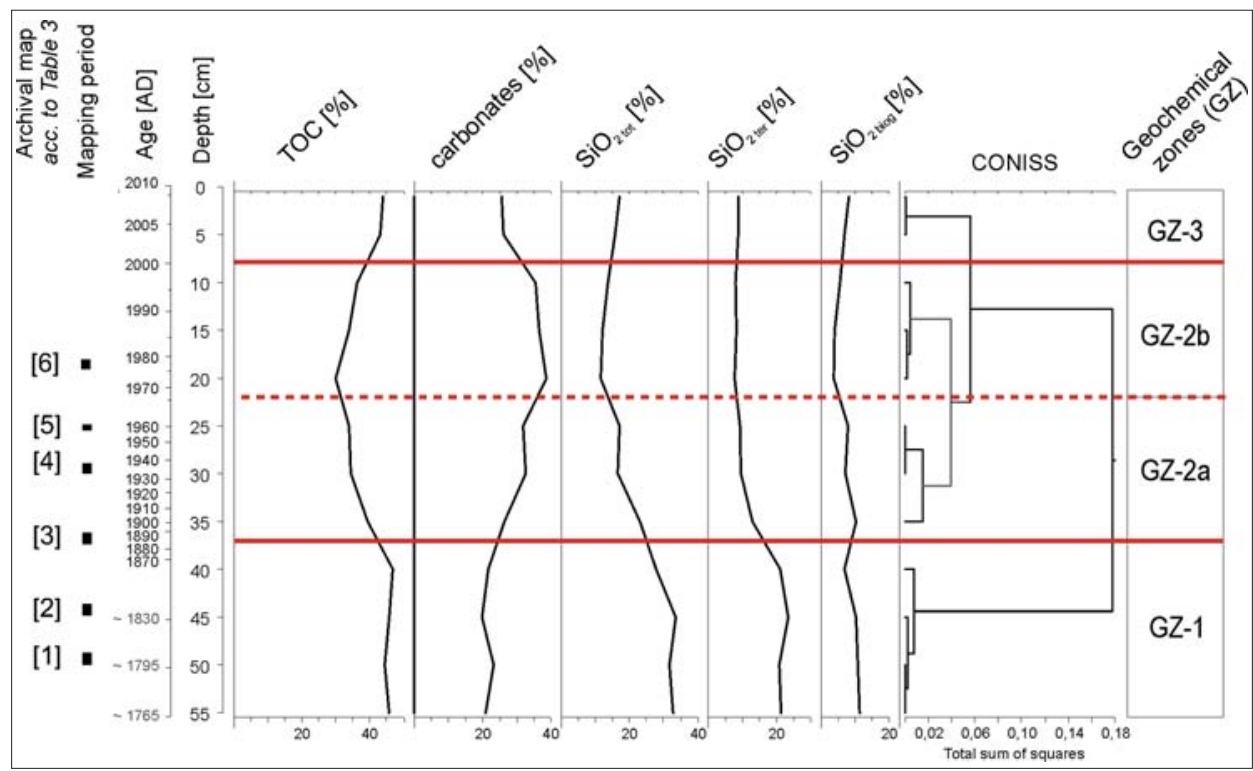

Fig. 7. Changes in the chemical composition of the Pni-A profile sediments (author's own study)

trend in TOC values (mean value for the sub-zone $32.0 \% \pm 1.9$ ) and in biogenic and terrigenous silica. In GZ-2a, the values of biogenic silica remained similar to GZ-1 $(8.3 \% \pm 1.3)$, whereas in GZ-2b, these declined significantly $(4.4 \% \pm 0.8)$.

GZ 3 (depth 1-5 cm, 2010-2004 AD). This zone was delimited based on the substantial decline in calcium carbonate $(28.0 \% \pm 0.3)$, as well as having high values of TOC $(47.1 \% \pm 0.4)$ comparable to these in GZ-1.

\section{DISCUSSION}

Data on changes of ecological status of Łęczna-Włodawa Lakes covering periods longer than a few decades are scarce. So far only few lakes: Kleszczów (Kornijów et al. 2016), Rotcze (Kowalewski et al. 2016) and Głębokie Uścimowskie (Kowalewski et al. 2013) have been comprehensively studied by applying paleolimnological methods. Although for all these lakes the development of macrophytes were very important phenomena, the results clearly point to the considerable differences in the trajectories of their changes within the last 200 years, as well as the important role of local factors in the process, especially with regard to transformation of their catchment.

Preliminary paleolimnological data for Lake Pniówno largely extend the spatial and ecological gradient of the studied ecosystems, by providing information 
regarding a site that is different hydrochemically and which has remained under long and permanent anthropogenic impact. The existence of the settlement of the Pniówno village at the southern shore of the lake is visible on the Heldensfeld map from the beginning of the $19^{\text {th }}$ century, but the village was first mentioned in historical sources as of $1414 \mathrm{AD}$ (Wawryniuk 2010). The quantitative data about the settlement dynamic since the early $19^{\text {th }}$ century (Fig. 8), together with the data regarding land-use (Fig. 3, Tab. 3) serve as the partial measure of the impact. Unfortunately, despite the long time array covered by the Pni-A sediments, due to the long history of settlement in the immediate vicinity of the lake and earlier than for most of the Lęczna-Włodawa Lakes, anthropogenic interference into hydrological settings of the catchment, the natural, pre-disturbance conditions of the lake were not covered by the presented analysis.

The high trophic status of the lake during the whole time span covered by the study is unambiguously confirmed by the very high total abundance of Cladocera, the low species diversity and, most importantly, by the strong codominance of three taxa associated with elevated nutrient status: B. longirostris, A. rectangula and C. sphaericus (Liu et al. 2014; Szeroczyńska 1998). It is worth highlighting that, despite the high target counting sum, not even a single occurrence of Cladocera taxa with preference towards low (oligo- or mesotrophic) trophic status were noted.

Interestingly, contrary to what might be expected, ecological changes of the ecosystem reflected in Cladocera phases, were not unidirectional with time and did not vary along with the increasing anthropogenic impact. The period of high trophy and low ecological status which should be understood as turbid water and phytoplankton-dominated condition of the lake (Scheffer, van Nes 2007), corresponds to the oldest of the identified phases (CAZ-1, GZ-1), when the settlement of the Pniówno village was yet the lowest (Fig. 8). By no doubt it is the agriculture and the rural sewage disposal that are major source of the nutrients in Lake Pniówno waters, therefore, one can expect that this impact should increase with farming intensity and population density, therefore, the opposite conclusions derived from paleolimnological analysis should be examined in detail. Despite the high uncertainty of age determination for this phase it can be assumed that these covers at least the period from the mid- $18^{\text {th }}$ to the mid- $19^{\text {th }}$ century. This estimation indicates that the bottommost section of the Pni-A core may partially correspond to the Little Ice Age (LIA, 1550-1800 AD). So far this cooling period has not been studied in detail in Polesie Region, whereas for the area of Poland an increase in the continentality of climate is reported. This is documented, e.g. by lowering peat accumulation rate, and the interruption of calcareous tufa deposition in the cupola spring mires (Dobrowolski et al. 2010). 


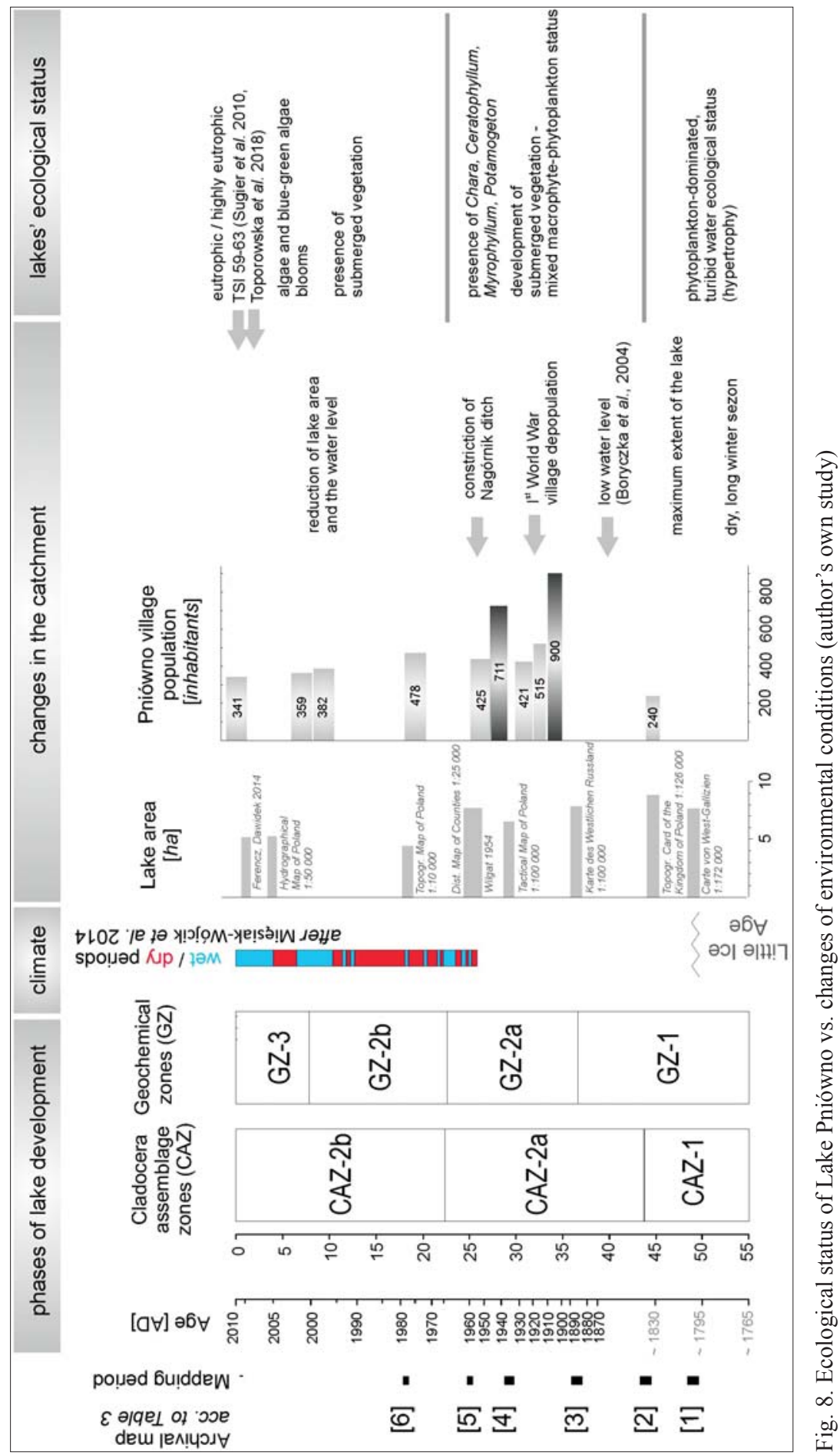


Assuming this climate-driven scenario, the extended ice-cover period and, consequently, the internal phosphorus load due to winter oxygen deficits, might have contributed to the high trophy status and turbid water state of Lake Pniówno. However, due to the temperate climate of the region, the high trophic status (hypertrophy) and absolute lack of macrophytes cannot result solely from the severity of climate. Even more plausible are additional, human-related factors, as mechanical destruction of aquatic vegetation during fishing activities (by using fishing dredge) or hemp retting practices. There are paleolimnological evidence for the cultivation of hemp in the region and using lakes for fibre processing since at least the early Middle Ages (Kulesza et al. 2011; Dobrowolski et al. 2015), until at least the end of the $19^{\text {th }}$ century. Multiple examples demonstrate that this practice inevitably causes severe water quality deterioration (Grönlund et al. 1986; Kulesza et al. 2011).

Despite the increasing (since the onset of $19^{\text {th }}$ century) transformation of the catchment by intensification of drainage, deforestation, agricultural land use and expanding settlement (Fig. 3), the subsequent change of lake ecological status (sub-phase CAZ-2a) brought its improvement rather than further decline. Although Cladocera are usually very reliable indicator of water level fluctuations with application of planktonic to littoral (p:1) ratio (Alhonen 1970; Korhola et al. 2000), in this study the community structure was so strongly shaped by elevated trophic status (Fig. 6), than the inference of this parameter is biased. A high share of $B$. longirostris and $C$. sphaericus hampers reconstruction of water level fluctuations, as during the blue-green algae blooms, both taxa can thrive outside of their typical environments (Gąsiorowski, Hercman 2005). Therefore, in this study, mostly data from archival maps contribute to reconstruction of this parameter. For this time, cartographic materials suggest slight lowering of the water level (Fig. 8). Although the water level information should always be interpreted with caution (Kowalewski 2012; Mięsiak-Wójcik 2018), this information is in line also with climatic data. According to literature, in the second half of the $19^{\text {th }}$ century, Poland faced prolonged drought (a decrease in the amount of precipitation since 1855, including low rainfall in the winter half-year, a time particularly important for shaping lake water resources), with a minimum in 1880 AD (Boryczka et al. 2004; Michalczyk et al. 2011). Although decline of water level in shallow lakes often results in increased of wind mixing, mobilization of nutrients and worsening the water quality (Wetzel 2001), the studied case might exemplify the opposite. The water decline interplays with submerged aquatic vegetation appearance and expansion (e.g. Ceratophyllum demersum and Characeae), as proved directly by presence of plant macrofossils, as well as by increased abundance of macrophyte-associated Cladocera taxa. This is a clear 
manifestation of the improvement of ecological conditions which is confirmed by the increase of Cladocera richness and diversity. The increased carbonate deposition, as well as development of benthic cladoceran taxa (A. quadrangularis, P. uncinatus) might prove the reduced oxygen deficits (Błędzki, Rybak 2016). Moreover, the decline of terrigenous silica stands for less intense catchment erosion at that time, whereas the sustained values of its biogenic form points to the high primary production of diatom and chrysophytes (Conley, Schelske 2002).

Despite the prerequisites for lowering of the water level, among the reasons for improving the ecological status the major population movements associated with World War I (primarily the relocation of the Ukrainian population in 1915-1940 AD) should also be taken into account. As a result, the number of inhabitants of the Pniówno village decreased by half (Apokryf Ruski). This decline coincides with first findings of Chara oospores. Moreover, during the second decade of $20^{\text {th }}$ century, the decline in the size of the hemp crops in Łęczna-Włodawa region is reported (Jarosz, Mędrek 2014), which also agrees well with the improvement of ecological status (Fig. 6). Given the above, the macrophyte development despite the high cultural eutrophication, might have resulted from alleviation of human activity, as well as the improvement of light conditions resulted from declined water level. The subsequent factor was found to be decisive for the development of macrophytes in Lake Rotcze in the second half of the $20^{\text {th }}$ century (Kowalewski et al. 2016).

However, while the transition from a turbid, phytoplankton-dominated regime to the conditions with developed submerged vegetation (Ceratophyllum, Chara) was a profound ecological change, this should not be considered as a transition to a macrophyte-dominated stable state, but rather transition to a mix macrophyte-phytoplankton regime (Scheffer, van Nes 2007).

The entire basin of Lake Pniówno is set into chalk bedrock (Suchora 2012), and its ground water supply plays an important role. This effect is stressed by Ferencz and Dawidek (2014), who also highlight its role in shaping lake water quality. The results of comprehensive hydrochemical measurements points also to the important role of flushing time for Lake Pniówno's ecological status (Ferencz, Dawidek 2014; Toporowska et al. 2018). Therefore, the major change in the surface hydrological network which was the inclusion of Lake Pniówno in the surface drainage network via Nagórnik ditch, resulted not only in the lowering of water level, but, most probably, via shortening of the retention time, also deeply affected reaction to groundwater supply. Moreover, the Nagórnik ditch also affected the range of the catchment (Fig. 4). The decrease in the lake water level due to the construction of the Nagórnik ditch and, probably, also the decrease in the amplitude of the lake water fluctuations, coincide with the warm and dry climatic 
period (Michalczyk et al. 2011; Mięsiak-Wójcik et al. 2014; Fig. 8). These overall changes are reflected consistently by CAZ- $2 b$ and GZ-2b sub-phases. At that time, an increase in the sedimentation rate and a further increase in the carbonate content (from 1970 to $1990 \mathrm{AD}, 36-39 \%$ ) were noted. As in the Cladocera species composition macrophyte-associated taxa decline only slightly, but solely Ceratophyllum hairs and Nymphaeaceae idioblasts, and no Chara oospores were identified. Still, they are listed as present in small abundance in 2005-2007, by Sugier et al. (2010). This discrepancy may result from the low resolution of analysis, or more probably, from declining as compared to CAZ-2a Chara population, which is usually attributed to trophy increase (Nõges et al. 2003). Moreover, the increase of taxa regarded as high trophy indicators $-B$. longiostris, A. rectagula, L. acanthocercoides (Szeroczyńska 1998) with the overall decline of diversity, point rather to the higher trophy and turbidity increase hypothesis.

Based on modern hydrochemical studies, Ferencz et al. (2017) attribute the poor quality and highly eutrophic status of Lake Pniówno water to slow water circulation in their catchment. It the context of the presented data it should be highlighted that before the 1970 s (early $19^{\text {th }}-$ mid $20^{\text {th }}$ century, before the construction of the Nagórnik ditch), the rate of the water exchange was even lower than nowadays, yet it did not determine its poor ecological status at that time. This supports the conclusion on the important role of other, interplaying factors in shaping the ecological status of this ecosystem.

\section{CONCLUSIONS}

Although the data is of a preliminary character, based on the presented analysis, the following facts regarding Lake Pniówno are indisputably confirmed:

- the lake has had high trophic status throughout the entire period of analysis (at least the last $\sim 200$ years);

- phytoplankton dominated, turbid water status of the lake in the CAZ-1 phase, when anthropogenic pressure in the catchment area and its surroundings (deforestation, drainage, settlement) was probably the least severe (judging from the lowest number of inhabitants). This might point to (1) the important role of hydroclimatic factors and limnological conditions in shaping the quality of this shallow lake or (2) other, not fully confirmed so far, anthropogenic activities harming the lake;

- improvement of the water quality and development of submerged vegetation was indicated to have occurred during the end of the $19^{\text {th }}$, till the first half of the $20^{\text {th }}$ century and its further (since the beginning of the $21^{\text {st }}$ century) deterioration in water quality has been coming about. 
The more detailed understanding of the mechanisms and dynamics of changes in the ecological status of this lake requires further, high resolution and multi-proxy research. To determine the lake's reference condition, a longer sediment sequence should be analyzed. However, regarding the scarcity of observational data on its water quality parameters and biocenosis, this study may serve as a framework for further investigation plans and for lake management.

\section{REFERENCES}

Affek A. 2013. Georeferencing of historical maps using GIS: As exemplified by the Austrian military surveys of Galicia. Geographica Polonica 86(4), 375-390.

Alhonen P. 1970. On the significance of the planktonic/littoral ratio in the cladoceran stratigraphy of lake sediments. Commentationes Biologicae 35, 1-9.

Apokryf Ruski. Online: https://www.apokryfruski.org/kultura/chelmszczyzna/pniowno/ (access: 20.10.2019).

Appleby P.G. 2001. Chronostratigraphic techniques in recent sediments. In: W.M. Last, J.P. Smol (eds.), Tracking Environmental Changes Using Lake Sediments, Vol. 1: Basin Analysis, Coring and Chronological Techniques (pp. 171-203). Dordrecht: Kluwer Academic Publishers.

Battarbee R.W., Anderson J.N., Jeppesen E., Leavitt P.R. 2005. Combining palaeolimnological and limnological approaches in assessing lake ecosystem response to nutrient reduction. Freshwater Biology 50(10), 1772-1780.

Błędzki L.A., Rybak J.I. 2016. Freshwater Crustacean Zooplankton of Europe: Cladocera \& Copepoda (Calanoida, Cyclopoida). Key to Species Identification, with Notes on Ecology, Distribution, Methods and Introduction to Data Analysis. Switzerland: Springer.

Boryczka J., Stopa-Boryczka M., Grabowska K., Wawer J., Błażek E., Skrzypczuk J. 2004. Groźne zjawiska pogodowe w Polsce. Atlas wspólzależności parametrów meteorologicznych i geograficznych w Polsce. Warszawa: Wydział Geografii i Studiów Regionalnych UW.

Buraczyński J., Wojtanowicz J. 1988.Objaśnienia do Szczegółowej mapy geologicznej Polski. Arkusz Sawin (749) 1:50 000. Warszawa: Wydawnictwo Geologiczne.

Carlson R.E. 1977. A Trophic State Index for lakes. Limnology and Oceanography 22, 361-369.

Chałubińska A., Wilgat T. 1954. Podział fizjograficzny województwa lubelskiego. Przewodnik V Zjazdu PTG Lublin, 3-44.

Chen G., Dalton C., Taylor D. 2010. Cladocera as indicators of trophic state in Irish lakes. Journal of Paleolimnology 44(2), 465-481.

Cleveland W.S., Devlin S.J. 1988. Locally-weighted regression: An approach to regression analysis by local fitting. Journal of the American Statistical Association 83, 596-610.

Conley D.J. Schelske C.L. 2002. Biogenic silica. In: W.M. Last, J.P. Smol (eds.), Tracking Environmental Changes Using Lake Sediments, Vol. 2: Physical and Chemical Methods (pp. 281293). Dordrecht: Kluwer Academic Publishers.

Dawidek J. 1998. Cechy fizyczno-chemiczne wód jeziornych. In: M. Harasimiuk, Z. Michalczyk, M. Turczyński (eds.), Jeziora tęczyńsko-włodawskie. Monografia przyrodnicza (pp. 113-127). Lublin: Biblioteka Monitoringu Środowiska, Wydawnictwo UMCS, PIOŚ. 
Dobrowolski R., Bałaga K., Kaszewski B.M. 2010. Próba określenia tendencji zmian klimatycznych na obszarze Polesia Zachodniego w ostatnich dwóch tysiącleciach na podstawie danych paleoekologicznych i pomiarów instrumentalnych. In: T.J. Chmielewski, D. Piasecki (eds.), Przyszłość krajobrazów hydrogenicznych w rezerwatach biosfery Europy (pp. 229-246). Lublin-Chełm: Trio System.

Dobrowolski R., Dzieńkowski T., Pidek I.A., Michczyńska D.J., Łojek J., Kulesza P. 2015. Naturalne i antropogeniczne zmiany warunków środowiska we wczesnym średniowieczu w rejonie Chełma w zapisie osadów biogenicznych stanowiska Bezedna. Prace i Materiały Muzeum Archeologicznego i Etnograficznego w Lodzi, seria Archeologiczna 46, 37-54.

Ferencz B., Dawidek J. 2012. Water exchange of three shallow Łęczna-Włodawa Lakes. Limnological Review 12(2), 65-72.

Ferencz B., Dawidek J. 2014. The flushing time based on underground supply in the upper-most located Łęczna-Włodawa Lakes. Scottish Geographical Journal 130(4), 243-251.

Ferencz B., Toporowska M., Dawidek J., Sobolewski W. 2017. Hydro-chemical conditions of shaping the water quality of shallow Łęczna-Włodawa Lakes (Eastern Poland). CLEAN-Soil, Air, Water 45(5), 1.

Fijałkowski D. 1959. Szata roślinna jezior i przylegających do nich torfowisk. Annales UMCS sec. B 14, 131-206.

Flynn W.W. 1968. The determination of low-levels of polonium-210 in environmental materials. Analytica Chemica Acta 43, 221-227.

Froyd C.A., Willis K.J. 2008. Emerging issues in biodiversity and conservation management: the need for a palaeoecological perspective. Quaternary Science Reviews 27(17-18), 1723-1732.

Gąsiorowski M., Hercman H. 2005. Recent sedimentation and eutrophication of Kruklin Lake after artificial drop in water-level in the middle of $19^{\text {th }}$ century. Studia Quaternaria 22, 17-25.

Grönlund E., Simola H., Huttunen, P. 1986. Paleolimnological reflections of fiber-plant retting in the sediment of a small clearwater lake. Hydrobiologia 143, 425-431.

Grimm E.C. 1992. Tilia Software. Springfield: Illinois State Museum.

Hammer Ø., Harper D.A., Ryan P.D. 2001. PAST: paleontological statistics software package for education and data analysis. Palaeontologia Electronica 4(1), 9.

Heiri O., Lotter A.F., Lemcke G. 2001. Loss on ignition as a method for estimating organic and carbonate content in sediments: reproducibility and comparability of results. Journal of Paleolimnology 25, 101-110.

Hennebelle A., Grondin P., Aleman J.C., Ali A.A., Bergeron Y., Borcard D., Blarquez O. 2018. Using paleoecology to improve reference conditions for ecosystem-based management in western spruce-moss subdomain of Québec. Forest Ecology and Management 430, 157-165.

Jarosz J., Mędrek K. 2014. Próba korelacji danych statystycznych i palinologicznych uprawy konopi i chmielu na Pojezierzu Lęczyńsko-Włodawskim. V Sesja Paleolimnologiczna „Płytkie jeziora jako obiekty badań paleolimnologicznych i sukcesji torfowiskowej”. Lublin.

Korhola A., Olander H., Blom T. 2000. Cladoceran and chironomid assemblages as qualitative indicators of water depth in subarctic Fennoscandian lakes. Journal of Paleolimnology 24(1), 43-54.

Kornijów R., Kowalewski G., Sugier P., Kaczorowska A., Gąsiorowski M., Woszczyk M. 2016. Towards a more precisely defined macrophyte-dominated regime: The recent history of a shallow lake in Eastern Poland. Hydrobiologia 772(1), 45-62. 
Kowalczyk C. 1977. Fauna skorupiaków jezior Pojezierza Łęczyńsko-Włodawskiego na tle warunków limnologicznych. Część II. Jeziora o III stopniu degradacji. Annales UMCS sec. C, 33.

Kowalewski G. 2012. Over 200 years of drainage practices and lake level drawdown in the Uściwierskie Lowering (Łęczna-Włodawa Lakeland). Limnological Review 12(4), 179-190.

Kowalewski G.A., Kornijów R., McGowan S., Kaczorowska A., Bałaga K., Namiotko T., Gąsiorowski M., Wasiłowska, A. 2016. Disentangling natural and anthropogenic drivers of changes in a shallow lake using palaeolimnology and historical archives. Hydrobiologia 767(1), 301-320.

Kowalewski G.A., Kornijów R., McGowan S., Woszczyk M., Suchora M., Bałaga K., Kaczorowska A., Gąsiorowski M., Szeroczyńska K., Wasiłowska, A. 2013. Persistence of protected, vulnerable macrophyte species in a small, shallow eutrophic lake (eastern Poland) over the past two centuries: Implications for lake management and conservation. Aquatic Botany 106, 1-13.

Kulesza P., Suchora M., Pidek I.A., Alexandrowicz, W.P. 2011. Chronology and directions of Late Glacial paleoenvironmental changes: A multi-proxy study on sediments of Lake Słone (SE Poland). Quaternary International 238(1-2), 89-106.

Kuna J. 2015. Metodyczne aspekty analiz przestrzennych GIS wykorzystujących dawne mapy topograficzne. In: A. Czerny (ed.), Dawne mapy topograficzne w badaniach geograficzno-historycznych (pp. 125-149). Lublin: Wydawnictwo UMCS.

Liu G., Liu Z., Gu B., Smoak J. M., Zhang Z. 2014. How important are trophic state, macrophyte and fish population effects on cladoceran community? A study in Lake Erhai. Hydrobiologia 736(1), 189-204.

Michalczyk Z., Chmiel S., Turczyński M. 2011. Lake water stage dynamics in the Łęczna-Włodawa Lake District in 1991-2010. Limnological Review 11(3), 113-122.

Mięsiak-Wójcik K. 2018. Analysis of water retention changes in selected lake-wetland catchments of West Polesie based on historical documents. Limnological Review 18(2), 59-75.

Mięsiak-Wójcik K., Turczyński M., Sposób J. 2014. Natural and anthropogenic changes of standing water bodies in West Polesie (East Poland). In: Proceedings of the $2^{\text {nd }}$ International Conference on Water Resources and Wetlands, 11-13.

Nevalainen L., Luoto T.P., Kultti S., Sarmaja-Korjonen K. 2012. Do subfossil Cladocera and chydorid ephippia disentangle Holocene climate trends? The Holocene 22(3), 291-299.

Nõges P., Tuvikene L., Feldmann T., Tõnno I., Künnap H., Luup H., Salujõe J., Nõges T. 2003. The role of charophytes in increasing water transparency: a case study of two shallow lakes in Estonia. Hydrobiologia 506(1-3), 567-573.

Oldfield F. 1977. Lakes and their drainage basins as units of sediment based ecological study. Progress in Physical Geography 1, 460-504.

Radwan S., Kowalczyk C., Podgórski W., Fall J. 1973. Materiały do hydrochemii Pojezierza Łęczyńsko-Włodawskiego. Część III. Właściwości fizyczne i chemiczne. Annales UMCS sec. C 28(10), 97-116.

Radwan S., Podgórski W., Kowalczyk C. 1971. Materiały do hydrochemii Pojezierza Łęczyńsko-Włodawskiego. Część I. Stosunki mineralne. Annales UMCS sec. C 26(13), 156-168.

Radwan S., Podgórski W., Kowalczyk C. 1972. Materiały do hydrochemii Pojezierza Łęczyńsko-Włodawskiego. Część II. Substancja organiczna i związki azotowe. Annales UMCS sec. C 27, 17-30. 
Scheffer M., van Nes E.H. 2007. Shallow lakes theory revisited: various alternative regimes driven by climate, nutrients, depth and lake size. In: R.D. Gulati, E. Lammens, N. De Pauw, E. Van Donk (eds.), Shallow Lakes in a Changing World (pp. 455-466). Dordrecht: Springer.

Smol J.P. 1992. Paleolimnology: An important tool for effective ecosystem management. Journal of Aquatic Ecosystem Health 1(1), 49-58.

Suchora M. 2012. Late-glacial cladoceran succession in three lakes of the Chełm Hills region (Łęczna-Włodawa lake group, SE Poland). Studia Quaternaria 29, 9-21.

Sugier P., Lorens B., Chmiel S., Turczyński M. 2010. The influence of Ceratophyllum demersum L. and Stratiotes aloides L. on richness and diversity of aquatic vegetation in the lakes of mideastern Poland. Hydrobiologia 656(1), 43-53.

Szeroczyńska K., 1998. Anthropogenic transformation of nine lakes in Central Poland from Mesolithic to modern times in the light of Cladocera analysis. Studia Geologica Polonica 112, $123-165$.

Szeroczyńska K., Sarmaja-Korjonen K. 2007. Atlas of subfossil Cladocera from central and northern Europe. Świecie: Friends of the Lower Vistula Society.

Toporowska M., Ferencz B., Dawidek J. 2018. Impact of lake-catchment processes on phytoplankton community structure in temperate shallow lakes. Ecohydrology 11(8).

Wawryniuk A. 2010. Wielki leksykon lubelsko-wotyńskiego Pobuża: historia, geografia, gospodarka, polityka, Vol. 2: Gmina Wierzbica, powiat chetmski. Chełm: Urząd Gminy Wierzbica.

Wetzel R.G. 2001. Limnology: Lake and River Ecosystems. Houston: Gulf Professional Publishing. Wilgat T. 1954. Jeziora Łęczyńsko-Włodawskie. Annales UMCS sec. B 8(3), 37-122.

Woszczyk M. 2011. Paleolimnologiczna interpretacja krzemionki biogenicznej - dyskusja na przykładzie wybranych jezior niżu polskiego. Badania Fizjograficzne, Seria A. Geografia Fizycz$n a, 165-179$. 